\title{
Optimum Digestible Valine to Lysine Ratio for Meat- Type Quails from 15 to 35 Days of Age
}

\section{-Author(s)}

\section{Alves WJ' \\ Viana GS" \\ Barreto SLT" \\ Muniz JCL" \\ Hannas MI" \\ Silva AD" \\ Arnaut PR" \\ Barros VRMS}

Universidade Estadual Paulista Júlio de Mesquita Filho, Jaboticabal, São Paulo, Brasil

" Universidade Federal de Viçosa, Viçosa, Minas Gerais, Brasil

\section{Mail Address}

Corresponding author e-mail address Gabriel da Silva Viana

Avenida Bruno Martinho, n 145, apt n $^{\circ} 103$, Fátima, Viçosa, Minas Gerais, 36570000, Brasil.

Tel: $\quad$ (5531) 38993314

Email: mail.gsviana@gmail.com

\section{-Keywords}

Branched-chain amino acids, Coturnix coturnix coturnix, digestible amino acids.

\section{ABSTRACT}

This study was conducted to estimate the dig. valine to lysine (Val:Lys) ideal ratio for meat-type quails from 15 to $35 \mathrm{~d}$ of age. A total of 385, 15-day-old not sexed quails, were randomly assigned to five treatments, each one seven times replicated with eleven quails per experimental unit. Experimental treatments consisted of five dig. Val:Lys ratios $(0.65 ; 0.70 ; 0.75 ; 0.80$ and 0.85$)$. Ideal dig. Val:Lys ratio was estimated using polynomial regression and linear broken-line regression model. Significant effect was considered when $p \leq 0.05$. Feed conversion ratio was not affected by dig. Val:Lys ratios in any of the assessed phases. From 15 to $21 \mathrm{~d}$ of age Val:Lys ratios increased linearly feed intake, weight gain and body weight. From 15 to $28 \mathrm{~d}$ of age, weight gain and body weight were both optimized by the Val:Lys ratio of 0.77. A linear effect of dig. Val:Lys ratios was observed on weight gain and final body weight from 15 to $35 \mathrm{~d}$ of age. From 15 to $35 \mathrm{~d}$ of age, according to linear broken-line regression model, the dig. Val:Lys ideal ratios for optimum final body weight and weight gain were 0.77 and 0.76 , respectively. Based on the results the estimated dig. Val:Lys ratio for optimum meat-type quail performance from 15 to $35 \mathrm{~d}$ of age is 0.77

\section{INTRODUCTION}

Increasing on commercial amino acid availability and rising on soybean meal and corn prices has become crystalline amino acid supplementation on low-protein diets an efficient strategy to reduce poultry production costs (Burley et al., 2013). Published reports have indicated that crystalline amino acid supplementation in lowprotein diets can support similar broiler performance to high-protein diets in different phases. Nevertheless, the decrease in dietary crude protein $(\mathrm{CP})$ content has become possible due to the establishment of broiler digestible amino acid requirements (e.g. methionine, lysine, threonine, tryptophan), which deficiency resultant from reduction on dietary $\mathrm{CP}$, is generally corrected by their dietary supplementation in crystalline form.

Digestible lysine requirements and its optimum relative ratio with dig. methionine + cysteine, threonine and tryptophan for meat-type quails from 15 to $35 \mathrm{~d}$ of age have been widely studied (Scherer et al., 2009; Ton et al., 2012; Ton et al., 2013; Ribeiro, 2015). Valine is considered the $4^{\text {th }}$ limiting amino acid in corn and soybean meal-based diets for broilers (Corzo et al., 2007; Rostagno et al., 2011). Based on this hypothesis, L-valine supplementation, as well as the amino acids afore mentioned, could potentially allow further reductions in dietary CP without compromising meat-type quail performance. Broiler responses to valine supplementation in different phases are available 
Alves WJ, Viana GS, Barreto SLT, Muniz JCL, Hannas MI, Silva AD, Arnaut PR, Barros VRMS

\section{Optimum Digestible Valine to Lysine Ratio for Meat- Type Quails from 15 to 35 Days of Age}

containing quail nutritional requirements. Thus, this study was conducted to determine the dig. Val:Lys ratio for optimum meat-type quail performance from 15 to $35 \mathrm{~d}$ of age.

\section{MATERIALS AND METHODS}

\section{Animal care and use}

All the procedures involving animal care and use were previously approved by the institutional Animal Care and Use Committee of the Universidade Federal de Viçosa (protocol no. 07/2016).

Table 1 - Ingredients and calculated composition of experimental diets.

\begin{tabular}{|c|c|c|c|c|c|}
\hline \multirow{2}{*}{ Ingredients (g/kg) } & \multicolumn{5}{|c|}{ Digestible valine-to-lysine ratios } \\
\hline & 0.65 & 0.70 & 0.75 & 0.80 & 0.85 \\
\hline Corn $(7.88 \%)$ & 687.90 & 687.90 & 687.90 & 687.90 & 687.90 \\
\hline Soybean meal (45.22\%) & 228.70 & 228.70 & 228.70 & 228.70 & 228.70 \\
\hline Corn gluten meal (60\%) & 14.00 & 14.00 & 14.00 & 14.00 & 14.00 \\
\hline Limestone & 9.30 & 9.30 & 9.30 & 9.30 & 9.30 \\
\hline Dicalcium phosphate & 11.20 & 11.20 & 11.20 & 11.20 & 11.20 \\
\hline Salt & 3.30 & 3.30 & 3.30 & 3.30 & 3.30 \\
\hline L-Lysine HCL (78\%) & 4.68 & 4.68 & 4.68 & 4.68 & 4.68 \\
\hline DL-Methionine (99\%) & 4.39 & 4.39 & 4.39 & 4.39 & 4.39 \\
\hline L-Threonine (98\%) & 2.57 & 2.57 & 2.57 & 2.57 & 2.57 \\
\hline L-Tryptophan (98\%) & 0.27 & 0.27 & 0.27 & 0.27 & 0.27 \\
\hline L-Valine $(96.5 \%)$ & 0.00 & 0.55 & 1.14 & 1.71 & 2.28 \\
\hline Corn Starch & 30.00 & 29.50 & 28.90 & 28.30 & 27.70 \\
\hline Mineral premix ${ }^{1}$ & 1.00 & 1.00 & 1.00 & 1.00 & 1.00 \\
\hline Vitamin premix ${ }^{2}$ & 1.00 & 1.00 & 1.00 & 1.00 & 1.00 \\
\hline Choline chloride (60\%) & 1.00 & 1.00 & 1.00 & 1.00 & 1.00 \\
\hline Coccidiostatic $^{3}$ & 0.50 & 0.50 & 0.50 & 0.50 & 0.50 \\
\hline Antibiotic ${ }^{4}$ & 0.10 & 0.10 & 0.10 & 0.10 & 0.10 \\
\hline Antioxidant ${ }^{5}$ & 0.10 & 0.10 & 0.10 & 0.10 & 0.10 \\
\hline \multicolumn{6}{|l|}{ Calculated composition } \\
\hline AMEn (kcal/kg) & 3,050 & 3,050 & 3,050 & 3,050 & 3,050 \\
\hline Crude protein (g/kg) & 175.00 & 175.00 & 175.00 & 175.00 & 175.00 \\
\hline Calcium (g/kg) & 7.00 & 7.00 & 7.00 & 7.00 & 7.00 \\
\hline Non-phytate phosphorous (g/kg) & 3.00 & 3.00 & 3.00 & 3.00 & 3.00 \\
\hline Sodium $(\mathrm{g} / \mathrm{kg})$ & 1.50 & 1.50 & 1.50 & 1.50 & 1.50 \\
\hline Potassium (g/kg) & 6.20 & 6.20 & 6.20 & 6.20 & 6.20 \\
\hline \multicolumn{6}{|l|}{ Digestible amino acids (g/kg) } \\
\hline Lysine & 11.00 & 11.00 & 11.00 & 11.00 & 11.00 \\
\hline Methionine + Cysteine & 9.24 & 9.24 & 9.24 & 9.24 & 9.24 \\
\hline Methionine & 6.78 & 6.78 & 6.78 & 6.78 & 6.78 \\
\hline Threonine & 8.25 & 8.25 & 8.25 & 8.25 & 8.25 \\
\hline Tryptophan & 1.98 & 1.98 & 1.98 & 1.98 & 1.98 \\
\hline Valine & 7.15 & 7.70 & 8.25 & 8.80 & 9.35 \\
\hline Isoleucine & 6.38 & 6.38 & 6.38 & 6.38 & 6.38 \\
\hline Leucine & 14.93 & 14.93 & 14.93 & 14.93 & 14.93 \\
\hline
\end{tabular}

${ }^{1}$ Composition/kg of product: Manganese 160g. Iron 100g. Zinc 100g. Copper 20g. Cobalt: 2g. lodine: $2 \mathrm{~g}$ and excipient. ${ }^{2}$ Composition/kg of product: Vit. A:12.000.000 U.I.. Vit D3:3.600.000 U.I.. Vit. E: 3.500 U.I.. Vit B1:2.500 mg. Vit B2: 8.000 mg. Vit B6:5.000 mg. Pantothenic acid: 12.000 mg. Biotin: 200 mg. Vit. K:3.000 mg. Folic acid: $1.500 \mathrm{mg}$. Nicotinic acid: $40.000 \mathrm{mg}$. Vit. B12: $20.000 \mathrm{mg}$. Selenium: $150 \mathrm{mg}$. and excipient. ${ }^{3}$ Salinomicin $60 \% .{ }^{4}$ Avilamicin. ${ }^{5}$ Butil-hidroxy-toluen. 
Alves WJ, Viana GS, Barreto SLT, Muniz JCL, Hannas MI, Silva AD, Arnaut PR, Barros VRMS
Optimum Digestible Valine to Lysine Ratio for MeatType Quails from 15 to 35 Days of Age

\section{Bird husbandry and experimental design}

One-day-old meat-type quails, vaccinated for Marek disease, were obtained from a local commercial hatchery. From 1 to $14 \mathrm{~d}$ post hatch, quails were housed in a controlled temperature room with a concrete floor covered with wood-shavings litter. Birds were fed diets (mash form) formulated according to Silva \& Costa (2009) nutritional recommendations for meat-type quails at initial phase. On d 15 posthatch, 385 not sexed quails (initial body weight of $64 \mathrm{~g} \pm 0.98 \mathrm{~g}$ ), were housed in a ventilated double curtain-sided house; and randomly allotted to five treatment groups, each one seven times replicated. The experimental unit consisted of a $50 \times 50 \times 30$ $\mathrm{cm}$ stainless steel cage, equipped with one nipple drinker and one stainless steel self-feeder, with eleven quails each. Quails had free access to feed (mash form) and water throughout the 20-day feeding trial. Environmental temperature and humidity were daily measured by four thermo-hygrometers, in different places inside the experimental room. Lighting program consisted of the supply of 24 hours of light a day (natural + artificial).

\section{Experimental diets}

The experimental diets (Table 1) were formulated to contain $175.00 \mathrm{~g}$ crude protein $/ \mathrm{kg}$ diet and $3,050 \mathrm{kcal}$ AMEn/kg diet. The other nutrients were supplied according to Silva \& Costa (2009) nutritional recommendations, except for digestible amino acids. Basal diet was formulated to meet the dig. methionine + cysteine, threonine and tryptophan relative ratios to dig. lysine described by Ribeiro (2015). A suboptimal level of digestible lysine (11.00 $\mathrm{g} / \mathrm{kg}$ diet) was considered to formulate the diets. The values of chemical and nutritional composition of the ingredients used to formulate diets were those described by Rostagno et al. (2011). The experimental treatments consisted of five dig. Val:Lys ratios (0.65; $0.70 ; 0.75 ; 0.80$ and 0.85$)$, which were obtained through the graded supplementation of L-Valine in a basal diet, valine-deficient, in replacement to cornstarch.

\section{Performance measurements}

At 21, 28 and $35 \mathrm{~d}$ of age, all quails and feeders were weighed to determine bird performance. Feed intake was divided by weight gain to obtain feed conversion ratio. Mortality was daily recorded to adjust feed intake and feed conversion.

\section{Statistical analysis}

The effects of dietary dig. Val:Lys ratios were analyzed as one-way ANOVA and the optimum dig. Val:Lys ratio for each dependent variable assessed was estimated using both polynomial (linear or quadratic) and linear broken-line regression model. Significant effect was considered when $p \leq 0.05$. The software package used to analyze data was Sistema de Análises Estatísticas e Genéticas (SAEG, 2007).

\section{RESULTS}

Maximum and minimum temperature means recorded inside the experimental room during the current trial were respectively 21.34 and $26.59{ }^{\circ} \mathrm{C}$, whereas the average humidity was $72.59 \%$. Digestible Val:Lys ratios increased linearly $(p<0.05)$ meat-type quail feed intake, weight gain and final body weight from 15 to $21 \mathrm{~d}$ of age (Table 2). From 15 to $28 \mathrm{~d}$ of age (Table 3), feed intake was not affected ( $p>0.05$ ) by dig. Val:Lys ratios, whereas weight gain and final body weight showed a quadratic $(p<0.05)$ response to dig. Val:Lys ratios, being both optimized at $0.77 \mathrm{dig}$. Val:Lys ratio. From 15 to $35 \mathrm{~d}$ of age, a linear increase $(p<0.05)$ on weight gain and final body weight was observed as dig. Val:Lys ratios increased, whereas feed intake was unaffected ( $p>0.05$ ) by treatments (Table 4). From 15 to $35 \mathrm{~d}$ of age, according to linear brokenline regression model, the breakpoint $(p<0.05)$ for weight gain and final body weight occurred at 0.76 and $0.77 \mathrm{dig}$. Val:Lys ratio, respectively. Feed conversion ratio was not influenced ( $p>0.05$ ) by treatments in any of the phases herein assessed.

Table 2 - Performance of meat-type quails fed experimental diets from 15 to $21 \mathrm{~d}$ of age.

\begin{tabular}{|c|c|c|c|c|}
\hline Val:Lys ratio & $\mathrm{Fl}^{1}(\mathrm{~g})$ & $W^{2}(g)$ & $\mathrm{FCR}^{3}(\mathrm{~kg} / \mathrm{kg})$ & $\mathrm{BW}^{4}(\mathrm{~g})$ \\
\hline 0.65 & 128.78 & 56.38 & 2.29 & 120.42 \\
\hline 0.70 & 131.95 & 59.08 & 2.23 & 122.97 \\
\hline 0.75 & 132.10 & 60.09 & 2.20 & 124.30 \\
\hline 0.80 & 132.37 & 60.35 & 2.19 & 124.33 \\
\hline 0.85 & 134.88 & 60.84 & 2.22 & 124.94 \\
\hline $\mathrm{CV}^{5}(\%)$ & 3.00 & 3.40 & 3.67 & 1.85 \\
\hline \multicolumn{5}{|l|}{$\mathrm{p}$-Value } \\
\hline Linear & $<0.05$ & $<0.01$ & 0.09 & $<0.01$ \\
\hline Quadratic & 0.99 & 0.08 & 0.12 & 0.18 \\
\hline Linear broken-line & 0.15 & 0.99 & 0.99 & 0.31 \\
\hline Item & \multicolumn{3}{|c|}{ Regression equations } & $\mathrm{R}^{2}$ \\
\hline $\mathrm{Fl}^{1}$ & \multicolumn{3}{|c|}{$Y=113.07+25.27 x$} & 0.85 \\
\hline$W^{2}$ & \multicolumn{3}{|c|}{$Y=44.03+20.42 x$} & 0.82 \\
\hline $\mathrm{BW}^{4}$ & \multicolumn{3}{|c|}{$Y=107.79+20.80 x$} & 0.82 \\
\hline
\end{tabular}

1 - feed intake. 2 - weight gain. 3 - feed conversion rate. 4 - body weight. 5 - Coefficient of variation 
Table 3 - Performance of meat-type quails fed experimental diets from 15 to $28 \mathrm{~d}$ of age.

\begin{tabular}{|c|c|c|c|c|}
\hline Val:Lys ratio & $\mathrm{Fl}^{1}(\mathrm{~g})$ & $W G^{2}(g)$ & $\mathrm{FCR}^{3}(\mathrm{~kg} / \mathrm{kg})$ & $\mathrm{BW}^{4}(\mathrm{~g})$ \\
\hline 0.65 & 275.27 & 106.98 & 2.57 & 171.02 \\
\hline 0.70 & 281.03 & 110.45 & 2.55 & 174.35 \\
\hline 0.75 & 280.65 & 111.77 & 2.51 & 175.97 \\
\hline 0.80 & 279.31 & 111.71 & 2.50 & 175.68 \\
\hline 0.85 & 276.12 & 110.07 & 2.51 & 174.12 \\
\hline $\mathrm{CV}^{5}(\%)$ & 3.70 & 3.01 & 3.85 & 2.01 \\
\hline \multicolumn{5}{|l|}{$p$-Value } \\
\hline Linear & 0.99 & 0.07 & 0.16 & 0.08 \\
\hline Quadratic & 0.19 & $<0.05$ & 0.99 & $<0.05$ \\
\hline Linear broken-line & 0.99 & 0.99 & 0.99 & 0.12 \\
\hline Item & \multicolumn{2}{|c|}{ Regression equations } & $\mathrm{R}^{2}$ & Val:Lys ratio \\
\hline$W^{2}$ & \multicolumn{2}{|c|}{$Y=-85.74+512.02 x-331.43 x^{2}$} & 0.99 & 0.77 \\
\hline $\mathrm{BW}^{4}$ & \multicolumn{2}{|c|}{$Y=-23.27+516.06 x-334.00 x^{2}$} & 0.99 & 0.77 \\
\hline
\end{tabular}

1 - feed intake. 2 - weight gain. 3 - feed conversion rate. 4 - body weight. 5 - Coefficient of variation

Table 4 - Performance of meat-type quails fed experimental diets from 15 to $35 \mathrm{~d}$ of age.

\begin{tabular}{|c|c|c|c|c|}
\hline Val:Lys ratio & $\mathrm{Fl}^{1}(\mathrm{~g})$ & $W G^{2}(g)$ & $\mathrm{FCR}^{3}(\mathrm{~kg} / \mathrm{kg})$ & $\mathrm{BW}^{4}(\mathrm{~g})$ \\
\hline 0.65 & 445.20 & 146.39 & 3.04 & 210.43 \\
\hline 0.70 & 457.12 & 149.91 & 3.05 & 213.81 \\
\hline 0.75 & 459.09 & 151.19 & 3.04 & 215.40 \\
\hline 0.80 & 460.03 & 153.31 & 3.00 & 217.29 \\
\hline 0.85 & 459.44 & 151.90 & 3.05 & 216.14 \\
\hline $\mathrm{CV}^{5}(\%)$ & 5.04 & 3.67 & 6.28 & 2.52 \\
\hline \multicolumn{5}{|l|}{$p$-Value } \\
\hline Linear & 0.27 & $<0.05$ & 0.99 & $<0.05$ \\
\hline Quadratic & 0.99 & 0.26 & 0.99 & 0.26 \\
\hline Linear broken-line & 0.99 & $<0.05$ & 0.13 & $<0.05$ \\
\hline Item & Regression equations & $\mathrm{R}^{2}$ & Plateau & Val:Lys ratio \\
\hline$W^{2}$ & $118.22+44.12 x$ & 0.96 & 151.90 & 0.76 \\
\hline $\mathrm{BW}^{4}$ & $182.09+44.33 x$ & 0.97 & 216.14 & 0.77 \\
\hline
\end{tabular}

1 - feed intake. 2 - weight gain. 3 - feed conversion rate. 4 - body weight. 5 - Coefficient of variation

\section{DISCUSSION}

Trials conducted to determine ideal amino acid profile for poultry involve expressing amino acid requirements as percentage of dig. Iysine requirement, which is generally supplied in a suboptimal level. In the current study, dietary dig. lysine, as well as dig. valine, was limiting in basal diet. The suboptimal level of dig. lysine used to formulate the basal diet was $11.00 \mathrm{~g} / \mathrm{kg}$ diet, which corresponds to $90 \%$ of dietary digestible lysine recommended by Silva \& Costa (2009) for growingfinishing meat-type quails. Therefore, our discussion did not have focus on dig. valine requirement, but rather on its ideal ratio with dig. lysine.

Although datasuggest that L-valine supplementation increases broiler feed intake (Corzo et al., 2008), quail feed intake was only influenced from 15 to $21 \mathrm{~d}$ of age $(p<0.05)$. Likewise, Batista et al. (2016) did not observe influence of dig. Val:Lys ratios on meat-type quail feed intake from 15 to $35 \mathrm{~d}$ of age. According to linear broken-line regression model, the estimated dig.Val:Lys ratio for optimum weight gain and final body weight from 15 to $35 \mathrm{~d}$ of age was 0.76 and 0.77 , respectively. Similarly, Silva \& Costa, (2009) recommended a 0.75 dig. Val:Lys ratio for meat-type quails at the same phase, while Corzo et al. (2007) and Rostagno et al. (2011) proposed a 0.78 dig. Val:Lys ratio for growingfinishing broilers. The estimate found in the current study was greater than that determined by Batista et al. (2016), who recommended a dig. Val:Lys of 0.52 for growing-finishing meat-type quails.

Valine, leucine and isoleucine dietary supply is essential to maintain poultry growth. However it is crucial to provide the ideal dietary balance of these branched-chain amino acids (BCAA), once they share the same absorptive system in the intestine and may compete for the intestinal transporters (Broer, 2008). Moreover, antagonism among BCAA extrapolates 
Alves WJ, Viana GS, Barreto SLT, Muniz JCL, Hannas MI, Silva AD, Arnaut PR, Barros VRMS
Optimum Digestible Valine to Lysine Ratio for MeatType Quails from 15 to 35 Days of Age intestinal absorption. The first step of BCAA catabolism involves their transamination, which results in their $\alpha$-keto acid production. Literature data have demonstrated that alpha-ketoisocaproate, the $\alpha$-keto acid produced from leucine transamination, enhances the branched-chain $\alpha$-keto acid dehydrogenase complex $(B C K D H)$, resulting in valine and isoleucine catabolism in pig and rat liver (Langer et al., 2000).

Table 5 - Regression equations of performance of meattype quails at $21 \mathrm{~d}$.

\begin{tabular}{lcc}
\hline Variable & Regression equations & $\mathrm{R}^{2}$ \\
\hline FI & $113.066+25.2686 x$ & 0.85 \\
WG & $44.0340+20.4189 x$ & 0.82 \\
FBW & $107.792+20.8000 x$ & 0.82 \\
\hline
\end{tabular}

The calculated leucine concentration in basal diet used in our study was $14.93 \mathrm{~g} / \mathrm{kg}$ diet, which corresponds to the ratio with digestible lysine of $136 \%$. Few data about meat-type quail leucine requirement are available in literature. However, considering that the estimative of the optimum dig. Val:Lysratio for meat-type quails herein obtained was close to that recommended by Rostagno et al. (2011) for broilers; it is probable that the ideal dig. ratio of leucine relative to dig.lysine for meat-type quails follows the same behavior. Based on such hypothesis, leucine-to-lysine ideal ratio for meat-type quails could be probably close to the ideal ratio described by Rostagno et al. (2011) for broilers (108\%). Thus, the higher leucine content in basal diet could have influenced the optimum dig. Val:Lys herein estimated.

Table 6 - Regression equations of performance of meat-type quails at $28 \mathrm{~d}$.

\begin{tabular}{lccc}
\hline Variable & Regression equations & $\mathrm{R}^{2}$ & Val:Lys ratio \\
\hline WG & $-80.0275+496.937 \mathrm{Val} /$ Lys $-321.373 \mathrm{Val} /$ Lys $^{2}$ & 0.99 & 0.77 \\
FBW & $17.3108+500.318 \mathrm{Val} /$ Lys $-323.522 \mathrm{Val} /$ Lys $^{2}$ & 0.99 & 0.77 \\
\hline
\end{tabular}

Maia (2013) reported negative effects of increasing dig. leucine-to-lysine ratio from 108 to $150 \%$ on broiler weight gain. Similarly, Allen \& Baker (1972), observed detrimental effects of excessive dietary leucine in broiler performance. According to these authors, such negative effects were attenuated by increasing in L-valine supplementation. Excessive valine supply has shown to decrease isoleucine concentration in laying hen plasma (Peganova \& Eder, 2003). However, in the current study valine appeared not to have interfered in isoleucine metabolism, once Val:Lys ratio greater than the ideal ratio estimated (0.77) did not compromise quail performance. Based on results, the dig. Val:Lys ratio for optimum meat-type quail performance from 15 to $35 \mathrm{~d}$ of age is 0.77 .
Table 7 - Regression equations of performance of meattype quails at $35 \mathrm{~d}$.

\begin{tabular}{lcccc}
\hline Variable & Regression equations & $\mathrm{R}^{2}$ & Plateau & Val:Lys ratio \\
\hline WG & $118.2183+44.117 x$ & 0.96 & 151.90 & 0.76 \\
FBW & $182.0919+44.331 x$ & 0.97 & 216.14 & 0.77 \\
\hline
\end{tabular}

\section{REFERENCES}

Allen NK, Baker DH. Quantitative efficacy of dietary isoleucine and valine for chick growth as influenced by variable quantities of excess dietary leucine. Poultry Science 1972;(51)4:1292-1298.

Batista E, Furlan AC, Marcato SM, Pozza PC, Ton APS, Grieser DO, et al. Exigência de valina e isoleucina para codornas de corte no período de um a 14 dias e de 15 a 35 dias de idade. Arquivo Brasileiro de Medicina Veterinária e Zootecnia 2016;(68)4:1000-1006.

Broer S. Amino acid transport across mammalian intestinal and renal epithelia. Physiological reviews 2008;(88)1:249-286.

Burley HK, Patterson PH, Elliot MA. Effect of a reduced crude protein, amino acid-balanced diet on hen performance, production costs, and ammonia emissions in a commercial laying hen flock. Journal of Applied Poultry Research 2013;(22)2:217-228.

Corzo A, Kidd MT, Dozier WA, Vieira SL. Marginality and needs of dietary valine for broilers fed certain all-vegetable diets. Journal of Poultry Applied Research 2007;(16)4:546-554.

Corzo A, Dozier WA, Kidd MT. Valine Nutrient Recommendations for Ross $\times$ Ross 308 broilers. Poultry Science 2008;(87)2:335-338.

Duarte KF, Junqueira OM, Domingues CHF, Filardi RS, Borges LL, Praes MFFM. Digestible valine requirements for broilers from 22 and 42 days old. Acta Scientiarum 2014;(36)2:151-156.

Langer S, Scislowski PWD, Brown DS, Dewey P, Fuller MF. Interactions among the branched-chain amino acids and their effects on methionine utilization in growing pigs: Effects on plasma amino- and ketoacid concentrations and branched-chain keto-acid dehydrogenase activity. British Journal of Nutrition 2000;(83)1:49-58.

Maia RC. Aminoácidos de cadeia ramificada e suas relações com lisina digestível para frangos de corte [dissertação]. Viçosa (MG): Universidade Federal de Viçosa; 2013.

National Research Council. Nutrient requirements of poultry. 9th ed. Washington: National Academy Press; 1994.

Peganova S, Eder K. Interactions of various supplies of isoleucine, valine, leucine and tryptophan on the performance of laying hens. Poultry Science 2003;(82)1:100-105.

Ribeiro CLN. Proteína bruta, relações aminoacídicas e lisina digestível em dietas para codornas de corte de 15 a 35 dias de idade [tese]. Viçosa (MG): Universidade Federal de Viçosa; 2015.

Rostagno HS, Albino LFT, Donzele JL, Gomes PC, Oliveira RF, Lopes DC, et al. Tabelas brasileiras para aves e suínos: composição de alimentos e exigências nutricionais. $3^{a}$ ed. Viçosa: Universidade Federal de Viçosa; 2011.

Scherer C. Exigência de energia metabolizável, lisina e metionina + cistina digestíveis para codornas de corte em fase de crescimento [tese] Maringá (PR): Universidade Estadual de Maringá; 2009.

Silva JHV, Costa FGP. Tabelas para codornas japonesas e européias: tópicos especiais, composição de alimentos e exigências nutricionais. $2^{a}$ ed. Jaboticabal: FUNEP; 2009. 
Alves WJ, Viana GS, Barreto SLT,

Muniz JCL, Hannas MI, Silva AD,

Arnaut PR, Barros VRMS
Optimum Digestible Valine to Lysine Ratio for MeatType Quails from 15 to 35 Days of Age

Ton APS, Furlan AC, Martins EN, Batista E, Pasquetti TJ, Scherer C, et al. Exigência de treonina digestível para codornas de corte no período de 15 a 35 dias de idade. Arquivo Brasileiro de Medicina Veterinária e Zootecnia 2013;2(65):505-512.

Universidade Federal de Viçosa. Sistema de analises estatísticas e genéticas - SAEG. Versão 8.0. Viçosa; 2007. 